\title{
Analysis of Proteins Synthesized by 9.5 Day Mouse Embryos: Determination of Cardiac and Noncardiac Proteins
}

\author{
MARGARET L. VAN KEUREN, ${ }^{1,2}$ RUXANDRA A. IACOB,${ }^{1}$ AND DAVID M. KURNIT ${ }^{1,2,3}$ \\ Departments of ${ }^{1}$ Pediatrics and ${ }^{3}$ Human Genetics and ${ }^{2}$ Howard Hughes Medical Institute, University of Michigan \\ School of Medicine, Ann Arbor, Michigan
}

\begin{abstract}
To catalog polypeptides that were specific to developing hearts, we separated ${ }^{35} \mathrm{~S}$-methionine-labeled 9.5 day mouse embryos into cardiac and noncardiac (carcass) components. Two-dimensional gels were then used to analyze the polypeptides synthesized in these two fractions. As a result, we were able to distinguish polypeptides that were specific to or increased in the heart as well as those polypeptides that were specific to or increased in the embryo minus the dissected heart. Using this analysis, there were two polypeptides that were cardiac-specific and 17 that were expressed at increased levels by at least twofold in the heart. The cardiac-specific polypeptides may be used in further studies to identify early cardiac tissue. Conversely, there were 26 polypeptides unique to noncardiac structures and an additional 15 that were increased in the carcass more than twofold relative to the heart. The noncardiac-specific polypeptides may be used to define contamination of putative cardiac tissue with noncardiac material. Two of the polypeptides expressed more abundantly in the carcass appeared to correspond to known proteins in the mouse fibroblast database, cyclin and tropomyosin 4 . Thus the heart at 9.5 days of murine development can be distinguished readily from the remainder of the embryonic mouse both macroscopically and on two-dimensional gels.
\end{abstract}

Key Words: Two-dimensional gel electrophoresis, Development, Polypeptides, Heart proteins

\section{INTRODUCTION}

The heart first becomes apparent late on the eighth day of murine development. By day 9.5, the heart is large enough to be separated readily from the developing embryo and to permit analysis of the polypeptides manufactured therein. Taking advantage of this separability, we catalogued polypeptides that are specific to and/or increased in the developing heart, as well as the converse. By doing so, we took advantage of an unusual opportunity to study early cardiogenesis at a molecular level.

\section{MATERIALS AND METHODS}

Day 9.5 embryos were derived from timed matings of C57BL/6J mice. Embryos were dissected and examined in serum-free Eagle's minimum essential medium without methionine under the dissecting microscope. Only 9.5 day embryos that were of Theiler (1972) stage 15 were used in this study. After examination, the 9.5 day embryos were cultured in $100 \mu l$ of serum-free methionine-free medium supplemented with $0.5 \mathrm{mCi} /$ $\mathrm{ml}$ of ${ }^{35} \mathrm{~S}-\mathrm{l}$-methionine ( $>1,000 \mathrm{Ci} / \mathrm{mmole}$, Amersham). After $3 \mathrm{~h}$ of culture in a $37^{\circ} \mathrm{C}$ incubator with $5 \% \mathrm{CO}_{2}$, the embryos were examined again under the dissecting microscope in medium without serum or methionine. The beating extrathoracic heart was visualized, removed with a forceps, and examined under a dissecting microscope to ensure that it was intact, including atria. It was then placed in a separate Eppendorf tube. The isolated heart and the heartless embryo carcass were then spun down and frozen at $-80^{\circ} \mathrm{C}$ separately.

Protein samples were prepared by the methods of Garrels (1979, 1983). Briefly, the heart and carcass were lysed in $25 \mu \mathrm{l}$ and $100 \mu$, respectively, of TS-SDS sample buffer (Protein Databases, Inc., Huntington Station, NY) and then heated in a boiling water bath for 2 min. Samples were cooled on ice and treated with DNAse/RNAse (Protein Databases, Inc.) to reduce viscosity. Samples were snap frozen in liquid nitrogen, packed on dry ice, and shipped to Protein Databases, Inc., for further processing. Following determination of trichloroacetic acid (TCA)-precipitable counts, samples were lyophilized and dissolved in isoelectric focusing buffer (9.5 M urea, 2\% NP-40, $100 \mathrm{mM}$ dithiothreitol [DTT] and $2 \%$ basic ampholines) at $37^{\circ} \mathrm{C}$ for $30 \mathrm{~min}$.

Two-dimensional gel electrophoresis was performed at Protein Databases, Inc., on an equilibrium twodimensional gel in a standardized manner as described elsewhere (Garrels, 1979, 1983). This study was restricted to the more informative and reproducible equilibrium format, which uses broad-range ampholytes (pH 3-10) in the first dimension, yielding a $\mathrm{pH}$ gradient of $4.0-7.8$. The second-dimension gel electrophoresis

Received December 26, 1990; accepted February 5, 1991.

Address reprint requests to Margaret L. Van Keuren, Howard Hughes Medical Institute, University of Michigan School of Medicine, $1150 \mathrm{~W}$. Medical Center Drive, MSRBI, Room 3520, Ann Arbor, MI 481090650 . 


\section{Heart}

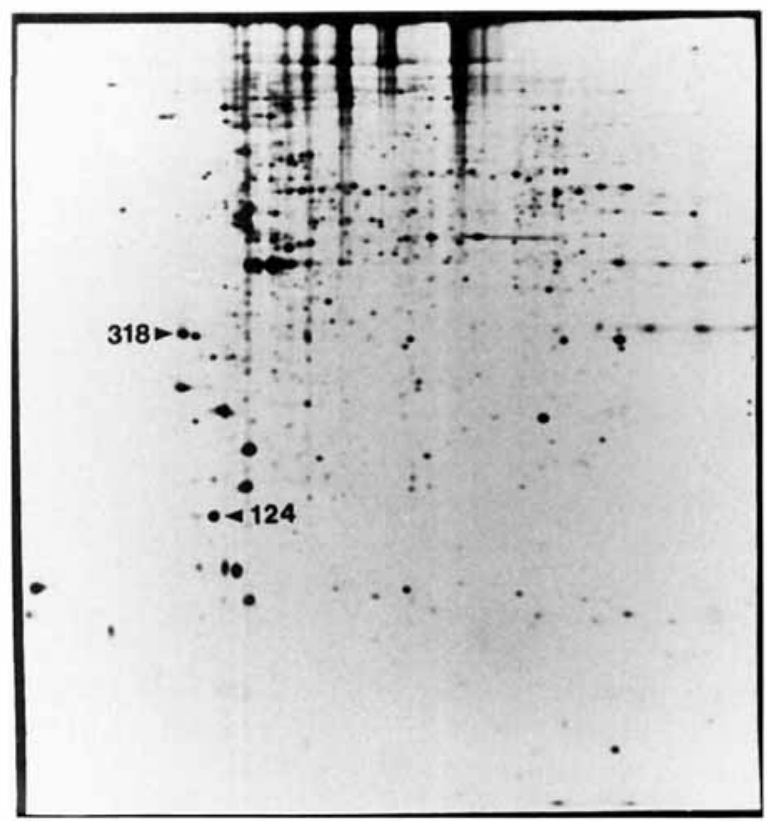

\section{Carcass}

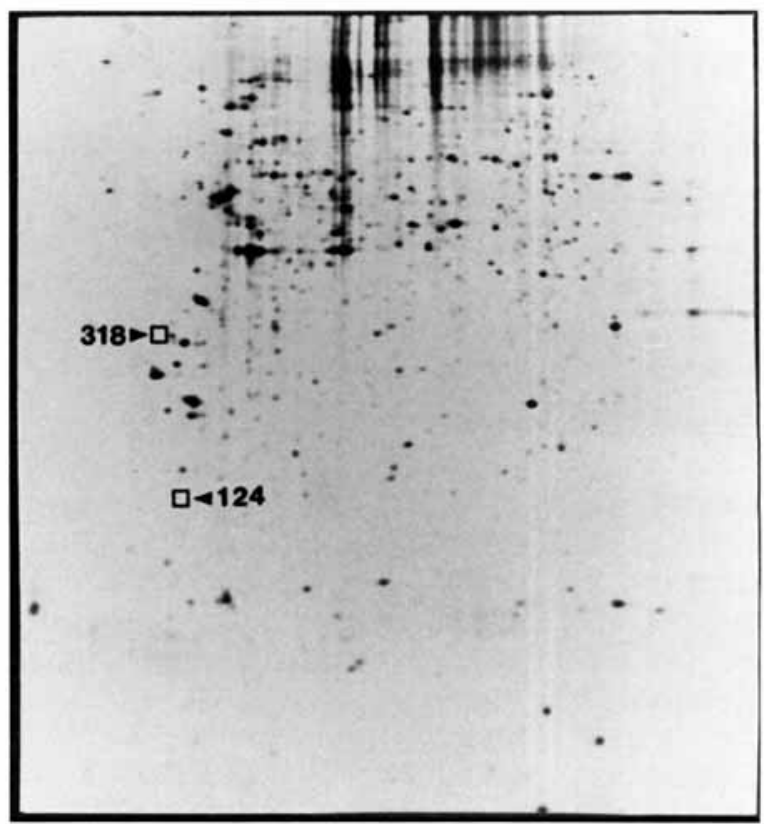

Fig. 1. Representative autoradiograms depicting proteins from an isolated heart sample (left) and from a carcass (embryo with heart removed; right). The heart-specific proteins, Nos. 124 and 318, are indicated.

was performed with $12.5 \%$ acrylamide, which creates a useful range of $12,000-200,000 \mathrm{M}_{\mathrm{r}}$ resolution. Gels with radioactive calibration strips containing known amounts of radioactive protein were processed for fluorography, and multiple autoradiographic exposures of each gel were made as described previously (Garrels, 1979, 1983; Garrels et al., 1984).

Autoradiograms were scanned with an Eikonix 78/79 camera system at $200 \mu \mathrm{m}$ resolution. Images were processed using the PDQUEST computer analysis programs based on the initial design of the Quest program (Garrels et al., 1984). For each gel, films corresponding to four autoradiographic exposure time points were developed to ensure that each spot was quantitated using an appropriate film on which the spot was present in the linear range for the film. The three most appropriate exposures were scanned and merged to form a composite image of a given embryo's protein synthesis. This provided a dynamic range of detection and allowed all proteins to be quantitated accurately. Images of heart proteins and of embryo minus heart proteins were assembled into matchsets and analyzed on a MassComp 68020 minicomputer. One image was selected to be the standard (reference) image against which protein spots in the other images of the matchset were matched. All data were normalized between samples. Following image editing, spot matching, and normalization, three statistical tests were performed. The $t$ test (Spurr and Bonini, 1973) was performed at the two-tailed 99\% confidence level $(P=0.01)$. In addition, the PDQUEST program performed the MannWhitney rank-sum test (Sokal and Rohlf, 1969) and the $\log t$ test (Spurr and Bonini, 1973) at the two-tailed 95\% confidence level $(P=0.05)$. Only spots satisfying all three tests are presented here.

The 95\% level test of significance for these three tests is automatically performed by the PDQUEST program. We increased stringency to $99 \%$ for the $t$ test. These levels are comparable to others used in studies employing two-dimensional gel electrophoresis to determine significant protein changes under various conditions. For example, Merril et al. (1981) used both $95 \%$ and 99\% levels of the t test to determine significant quantitative alterations in labeled phytohemaglutinin-stimulated lymphocytes from Lesch-Nyhan syndrome patients and controls; the $95 \%$ level of the $t$ test was also used to study cerebrospinal fluid proteins in neurological disease patients by Harrington et al. (1984); and a study of human brain proteins from cortical sections obtained under different conditions used the $t$ test at 95\%, 97.5\%, and 99\% levels (Narayan et al., 1984).

\section{RESULTS}

The 9.5 day embryo was separated mechanically into two fractions, the embryonic heart and the remainder carcass. Two-dimensional protein gel electrophoresis was performed on each fraction, resulting in gels of six different paired hearts and carcasses. Representative 


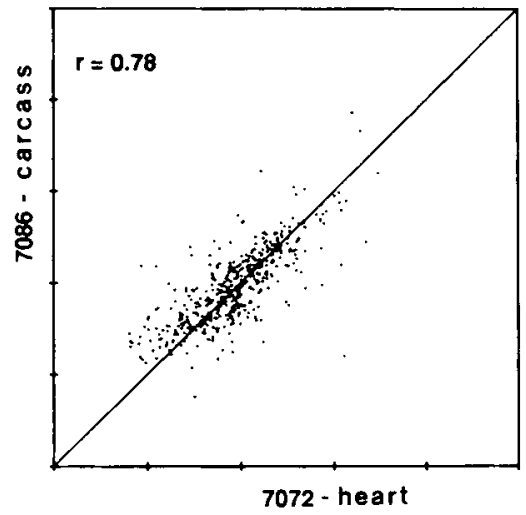

Fig. 2. Representative scatterplot showing relatedness of two gel images. Each matched spot is plotted as a point according to its quantitation in the first gel ( $\mathrm{x}$ axis) and its quantitation in the second gel ( $y$ axis). The correlation coefficient is $r$.

autoradiograms depicting the polypeptides synthesized in 9.5 day hearts and 9.5 day carcasses are displayed in Figure 1. A composite image of each gel was formed by merging three different exposures to obtain linear readings on the gamut of abundantly to nonabundantly expressed polypeptides. Figure 2 depicts a scatterplot showing the relatedness of images obtained from the two-dimensional gels. Computer analysis was performed to distinguish proteins that differed significantly in quantity between the two groups (embryonic heart and remainder carcass) as well as qualitative differences (specific to one or the other group). These putative significant protein spots were each examined critically in all autoradiograms for authenticity. Spots that were inconsistent, faint, obscured in a streak or smudge, or otherwise of questionable quality or reliability were eliminated.

The final results of this analysis are given in Tables 1 and 2 . Table 1 lists the spots that were specific to or increased significantly in the developing heart. There were two polypeptides that were cardiac-specific and 17 that were increased at least twofold in the heart. In all, there were 33 polypeptide spots judged to be increased significantly in hearts by the three statistical tests. Tables 1 and 2 list the spots that were specific to or increased in the embryo carcass minus the developing heart. There were 26 polypeptides unique to the carcass and 15 that were increased over twofold relative to the heart. In all, Table 2 lists 63 polypeptides that were increased significantly in carcasses by all three statistical tests. Table 3 lists the spot numbers of polypeptides identified previously in a mouse fibroblast database (Blose, 1986). Two (Nos. 302 and 201, cyclin and tropomyosin 4, respectively) appeared to be decreased significantly in the heart tissue.

\section{DISCUSSION}

Cardiac-specific isoforms of several protein groups have been identified. Myosin, the major contractile protein in all muscle cells, is encoded by a multigene family. Cardiac-specific isoforms are the result of heterogeneity of $\alpha$ and $\beta$ isoforms of the myosin heavy chain (reviewed in Bandman, 1985). Actin, another component of muscles, consists of a group of highly conserved proteins and is also encoded by a multigene family. Cardiac-specific isoforms have been described (reviewed in Obinata et al., 1981; Garrels and Gibson, 1976). In mouse, various isolated and cloned actin and myosin isoform genes have been mapped to several different chromosomes (Czosnek et al., 1982, 1983; Crosby et al., 1989). Cardiac-specific isoforms of other proteins, such as cytochrome $c_{1}$ (Yu et al., 1972), have been described. Some cardiac muscle protein components were identified in a two-dimensional electrophoresis study of rat cardiac samples (Tanaka and Kawamura, 1988). However differences in gel patterns make comparison with our study difficult.

The work reported here resulted in the identification of a number of polypeptides whose synthesis depends on the tissue of origin. Two of the proteins present in significantly lower quantity in the heart tissue, by 1.98- and 5.18-fold, appeared to be cyclin and tropomyosin 4, respectively. Cyclin is a ubiquitous cell cycleregulated nuclear protein whose rate of synthesis is correlated with the proliferative state of cultured cells and tissues. It was shown to be identical to proliferating cell nuclear antigen (PCNA) as well as the auxuliary protein of mammalian DNA polymerase $\delta$ (reviewed in Celis et al., 1987). Its decrease in quantity may reflect a decrease in the proportion of rapidly proliferating cells in cardiac tissue. Tropomyosin is a ubiquitous protein that is a component of the contractile apparatus of all cells. Several isoforms have been described, including five distinguishable by monoclonal antibodies in cultured rat cells (Matsumura et al., 1983). Their positions on two-dimensional protein gels have been

TABLE 1. Heart-Specific Proteins and Those That Show Large (more than twofold) Changes in the Heart Compared With the Carcass

\begin{tabular}{rccc}
\hline Spot No. & Fold change & $\mathrm{M}_{\mathrm{r}}(\mathrm{kD})$ & $\mathrm{pI}$ \\
\hline 124 & Heart only & 21.4 & 4.90 \\
318 & Heart only & 34.7 & 4.83 \\
1119 & 64.07 & 18.5 & 5.07 \\
1111 & 21.01 & 23.2 & 5.15 \\
1126 & 15.31 & 18.1 & 4.97 \\
1109 & 10.96 & 25.8 & 5.19 \\
7503 & 5.62 & 54.3 & 7.23 \\
6112 & 5.03 & 18.0 & 6.78 \\
2405 & 4.91 & 44.8 & 5.55 \\
3312 & 4.40 & 35.0 & 5.70 \\
1414 & 4.25 & 41.8 & 5.20 \\
304 & 3.72 & 34.3 & 4.88 \\
3314 & 3.59 & 36.6 & 6.67 \\
7307 & 2.57 & 33.7 & 7.12 \\
3202 & 2.45 & 28.6 & 5.78 \\
7416 & 2.39 & 40.6 & 7.10 \\
603 & 2.38 & 66.2 & 4.88 \\
2413 & 2.32 & 44.9 & 5.47 \\
5203 & 2.22 & 27.8 & 6.61 \\
\hline
\end{tabular}


TABLE 2. Seventy-Seven Additional Proteins Also Significantly Different in the Comparison*

\begin{tabular}{|c|c|c|c|c|c|c|c|}
\hline Spot No. & Fold change & $\mathrm{M}_{\mathrm{r}}(\mathrm{kD})$ & pI & Spot No. & Fold change & $\mathrm{M}_{\mathrm{r}}(\mathrm{kD})$ & pI \\
\hline 2418 & 1.93 & 44.2 & 5.41 & 6710 & -2.25 & 79.7 & 6.88 \\
\hline 4206 & 1.87 & 29.8 & 6.22 & 5504 & -2.34 & 50.8 & 6.60 \\
\hline 6506 & 1.86 & 51.6 & 6.97 & 5514 & -2.37 & 49.9 & 6.42 \\
\hline 4309 & 1.85 & 33.8 & 6.19 & 5216 & -2.42 & 30.4 & 6.35 \\
\hline 2221 & 1.83 & 28.4 & 5.50 & 2408 & -2.50 & 39.5 & 5.59 \\
\hline 1708 & 1.82 & 101.0 & 5.08 & 3606 & -2.60 & 66.4 & 5.68 \\
\hline 4404 & 1.80 & 45.5 & 6.31 & 6709 & -2.64 & 79.4 & 6.84 \\
\hline 3306 & 1.75 & 34.9 & 5.82 & 7301 & -2.67 & 37.6 & $>7.80$ \\
\hline 4209 & 1.67 & 27.8 & 6.10 & 4507 & -2.83 & 52.9 & 6.30 \\
\hline 6402 & 1.61 & 40.2 & 6.97 & 3001 & -2.97 & 14.9 & 5.98 \\
\hline 2121 & 1.61 & 20.5 & 5.40 & 201 & -5.18 & 31.1 & 4.90 \\
\hline 6204 & 1.60 & 27.7 & 6.98 & 7310 & -11.08 & 35.5 & 7.08 \\
\hline 7007 & 1.44 & 16.7 & 7.24 & 308 & - $^{a}$ & 33.4 & 4.75 \\
\hline 2308 & 1.37 & 36.1 & 5.50 & 310 & - & 33.4 & 4.87 \\
\hline 1416 & -1.32 & 38.5 & 5.03 & 707 & - & 86.0 & 4.70 \\
\hline 2214 & -1.36 & 32.2 & 5.35 & 1122 & - & 24.2 & 5.04 \\
\hline 3014 & -1.36 & 17.7 & 5.66 & 1124 & - & 24.9 & 5.00 \\
\hline 7415 & -1.36 & 44.4 & 7.13 & 1218 & - & 27.3 & 4.98 \\
\hline 7316 & -1.40 & 37.6 & 7.16 & 1221 & - & 27.3 & 5.03 \\
\hline 6616 & -1.44 & 60.3 & 6.91 & 1222 & - & 30.0 & 5.00 \\
\hline 4107 & -1.46 & 23.8 & 6.19 & 1329 & - & 35.2 & 4.96 \\
\hline 7508 & -1.48 & 52.8 & 7.16 & 3003 & - & 14.6 & 5.93 \\
\hline 3209 & -1.53 & 29.6 & 5.74 & 3006 & - & 16.6 & 5.85 \\
\hline 3408 & -1.56 & 38.8 & 5.67 & 3210 & - & 31.7 & 5.68 \\
\hline 6213 & -1.58 & 30.7 & 6.84 & 3212 & - & 31.0 & 5.65 \\
\hline 6308 & -1.59 & 35.7 & 6.92 & 3302 & - & 36.9 & 5.83 \\
\hline 5306 & -1.60 & 35.1 & 6.58 & 3307 & - & 35.0 & 5.87 \\
\hline 6313 & -1.61 & 34.5 & 6.95 & 3410 & - & 38.8 & 5.84 \\
\hline 3112 & -1.63 & 25.8 & 5.78 & 4305 & - & 34.4 & 6.28 \\
\hline 7512 & -1.69 & 51.2 & 7.12 & 4502 & - & 55.2 & 6.29 \\
\hline 5513 & -1.73 & 47.1 & 6.41 & 6305 & - & 36.5 & 6.91 \\
\hline 2201 & -1.78 & 30.0 & 5.65 & 6413 & - & 40.6 & 6.91 \\
\hline 4403 & -1.79 & 44.0 & 6.30 & 6518 & - & 48.6 & 6.86 \\
\hline 6009 & -1.79 & 16.5 & 6.87 & 6711 & - & 79.4 & 6.98 \\
\hline 3523 & -1.97 & 57.8 & 5.67 & 7209 & - & 27.7 & 7.25 \\
\hline 302 & -1.98 & 32.8 & 4.95 & 7302 & - & 36.2 & 7.30 \\
\hline 5109 & -2.10 & 22.3 & 6.52 & 7421 & - & 40.0 & 7.04 \\
\hline 7317 & -2.19 & 37.4 & 7.29 & 7504 & - & 53.0 & 7.32 \\
\hline 1220 & -2.23 & 27.5 & 5.22 & & & & \\
\hline
\end{tabular}

*There were 1,176 polypeptide spots in the carcass film used as the standard. Fold change = average quantitation of (heart/carcass) if heart is more than carcass and -(carcass/ heart) if carcass is more than heart.

a-, carcass only.

determined in rat (Garrels and Franza, 1989) and mouse (Blose, 1986) cells. The quantitative variation shown in this study may reflect a tissue-specific distribution of the isoforms. Two possibilities for this decrease are that all heart cells show this decrease in synthesis and that a subset of cells is responsible for this difference.

This work was designed to provide a "road map" of polypeptide synthesis that is keyed to cardiogenesis. The polypeptides so identified have two major roles. Analytically, the synthesis (or lack of same) of given polypeptides can be used to identify cardiac-specific structures in embryogenesis. In particular, spots 124 and 318 furnish cardiac-specific markers. Embryonic tissues expressing these polypeptides are presumably the anlage of the heart. Thus these spots may represent sensitive molecular markers for cardiogenesis and as such would be of obvious importance for developmental studies. Furthermore, the existence of a number of polypeptides not synthesized in the heart (Table 2) would indicate the presence of noncardiac tissue. Elucidation of these polypeptides will lead to increased understanding of our knowledge of cardiogenesis. In particular, isolation of proteins synthesized in the developing heart but not in the remainder of the embryo represents a novel approach to understanding and perturbing the molecular events that underlie cardiogenesis. This technology is compatible with and adds to molecular studies of nucleic acid metabolism centering on heart development.

\section{ACKNOWLEDGMENTS}

This work was supported by grant 5RO1 HL37703 from the National Institutes of Healths. D.M.K. is an 
TABLE 3. Location of Mouse Proteins Identified Previously (Blose, 1986)

$\begin{array}{ll}\text { Heat shock protein } 73 & 2606 \\ \text { Heat shock protein } 80 & 1607 \\ \text { Heat shock protein } 90 & 1703 \\ \text { Heat shock protein } 100 & 1708 \\ \text { Intermediate filament-associated } & 2717 \\ \quad \text { protein } & 2711 \\ \alpha \text {-Actinin } & 1504 \\ \text { Vimentin } & 1515 \\ \alpha \text {-Tubulin } & 1513 \\ \beta \text {-Tubulin } & 1405,2428,2426,2429,2427 \\ \text { Actin isoforms } & 302 \text { (significantly decreased in heart; Table 2) } \\ \text { Cyclin } & 201 \text { (significantly decreased in heart; Table 2) } \\ \text { Tropomyosin-4 } & 1216 \\ \text { Tropomyosin-5 } & \end{array}$

Investigator and M.L.V. is a Senior Associate of the Howard Hughes Medical Institute. The contributions of Dr. William M. Layton are gratefully acknowledged.

\section{REFERENCES}

Bandman $\mathrm{E}$ (1985): Myosin isoenzyme transitions in muscle development, maturation, and disease. In GH Bourne, JF Danielli, KW Jeon (eds): "International Review of Cytology, Vol 97." Orlando, FL: Academic Press, pp 97-132.

Blose SH (1986): The mouse NIH/3T3 cell line protein database developed from computer-analyzed two-dimensional gels: Key protein identification by experiments and amino acid ratios. In MJ Dunn (ed): "Electrophoresis '86 (Proceedings of the fifth meeting of the International Electrophoresis Society)." London: VCH Verlagsgesellschaft, pp 552-555.

Celis JE, Madsen P, Celis A, Nielson HV, Gesser B (1987): Cyclin (PCNA, auxiliary protein of DNA polymerase $\delta$ ) is a central component of the pathway leading to DNA replication and cell division. FEBS Lett 220:1-7.

Crosby JL, Phillips SJ, Nadeau JH (1989): The cardiac actin locus (actc-1) is not on mouse chromosome 17 but is linked to $\beta_{2^{-}}$ microglobulin on chromosome 2. Genomics 5:19-23.

Czosnek H, Nudel U, Mayer Y, Barker PE, Pravtcheva DD, Ruddle FH, Yaffe D (1983): The genes coding for the cardiac muscle actin, the skeletal muscle actin and the cytoplasmic $\beta$-actin are located on three different mouse chromosomes. EMBO J 2:1977-1979.

Czosnek H, Nudel U, Shani M, Barker PE, Pravtcheva DD, Ruddle FH, Yaffe D (1982): The genes coding for the muscle contractile proteins, myosin heavy chain, myosin light chain 2 , and skeletal muscle actin are located on three different mouse chromosomes. EMBO J 1:1299-1305.

Garrels JI (1979): Two-dimensional gel electrophoresis and computer analysis of proteins synthesized by clonal cell lines. J Biol Chem 254:7961-7977.

Garrels JI (1983): Quantitative two-dimensional gel analysis of pro- teins. In R Wu, L Grossman, K Moldave (eds): "Methods in Enzymology, Vol 100." New York: Academic Press, pp 411-423.

Garrels JI, Farrar JT, Burwell CB (1984): The QUEST system for computer-analyzed two-dimensional gel electrophoresis of proteins. In JE Celis, R Bravo (eds): "Two-Dimensional Gel Electrophoresis of Proteins." New York: Academic Press, pp 37-91.

Garrels JI, Franza R (1989): The REF52 protein database. J Biol Chem 264:5283-5298.

Garrels JI, Gibson W (1976): Identification and characterization of multiple forms of actin. Cell 9:793-805.

Harrington MG, Merril CR, Goldman D, Xu X, McFarlin DE (1984): Two-dimensional electrophoresis of cerebrospinal fluid proteins in multiple sclerosis and various neurological diseases. Electrophoresis 5:236-245.

Matsumura F, Yamashiro-Matsumura S, Lin JJ (1983): Isolation and characterization of tropomyosin-containing microfilaments from cultured cells. J Biol Chem 258:6636-6644.

Merril CR, Goldman D, Ebert M (1981): Protein variations associated with Lesch-Nyhan syndrome. Proc Natl Acad Sci USA 78:64716475.

Narayan RK, Heydorn WE, Creed GJ, Kornblith PL, Jacobowitz DM (1984): Proteins in normal, irradiated, and postmortem human brain quantitatively compared by using two-dimensional gel electrophoresis. Clin Chem 30:1989-1995.

Obinata T, Maruyama K, Sugita H, Kohama K, Ebashi S (1981): Dynamic aspects of structural proteins in vertebrate skeletal muscle. Muscle Nerve 4:456-488.

Sokal RR, Rohlf FJ (1969): "Biometry: The Principles and Practice of Statistics in Biological Research." San Francisco: W.H. Freeman and Co., pp 391-395.

Spurr WA, Bonini CP (1973): "Statistical Analysis for Business Decision." Homewood, IL: RD Irwin, Inc., pp 292-298, 704.

Tanaka T, Kawamura K (1988): Cardiac muscle protein analysis by high-resolution and microscale two-dimensional gel electrophoresis. Electrophoresis 9:94-100.

Theiler K (1972): "The House Mouse." New York: Springer-Verlag.

Yu CA, Yu L, King TE (1972): Preparation and properties of cardiac cytochrome $c_{1}$. J Biol Chem 247:2012-2019. 